\title{
Application of Micromorphology to Study Manuring Practices: A Case Study from Bronze Age in Cornwall, UK
}

\author{
Satya Dev* \\ Palaeo Research Society, Ghumarwin, India
}

Submission: August 16, 2018; Published: September 04, 2018

*Corresponding author: Satya Dev, Palaeo Research Society, IPH Colony, Ghumarwin India, Email: satyadevk@gmail.com

\begin{abstract}
The arable soils from Bronze Age settlement of Gwithian in Cornwall (UK) were analysed using micromorphology to recognise manuring practices over time. The analysis was conducted to determine whether the Gwithian farmers used fertilizers during Bronze Age? If they have used fertilizers, the aim of this research is also to identify which material were used. Moreover, it also aims to investigate if the sandy horizons at Gwithian (context 602 in layer 4) were stabilised by adding the midden material. Lastly, the research also describes if the context 606 was used for agricultural activity or was it a neglected area? The results of this study identify five phases of occupations where manures were used. The occurrence of rubified fine mineral, ash particles, decomposed wood, charred wood fragment with original tissue structure, shells and identifications of phytoliths from phase I and phase II of Early Bronze Age (c $1800 \mathrm{Cal}$ BC) suggest that this material derived from manure heap, indicating accumulation of household waste dominated by fire residues. The occurrence of phytoliths indicates to herbivore dung component.

The identifications of planar voids and the sandy grain aggregates surrounded by dusty clay coatings may indicate to practice of tillage and ploughing activities during these phases. The Early/Middle Bronze Age (phase III - context 606=6) is characterised by wind-blown sandy horizons and anthropogenic evidence were not identified from the field evidence [1]. Thin section analysis also did not show any traces of wood, burnt wood, and the pottery. However, soil aggregates surrounded by fine material may indicate that arable soils were raised by manuring practice. Moreover, few traces of yellowish porous material are also identified, which is interpreted as bone. The phase IV is ascribed to Middle Bronze Age (c 1500-1200 cal. BC). The results from this phase demonstrate that arable soils are characterised by blown sands, shells, ashes from hearth, and bones. The findings of bones, decomposed wood, charred wood, ashes from grasses and woods, rubified iron nodules, burnt carbonate, bones and evidence of animal dung demonstrate that farmers brought midden material to sandy horizons $(602=4)$ of this site. They used midden material not only to stabilise them, but also for increasing the fertility of soils. The Middle/Late Bronze Age (c 1300-900 cal. BC) is assigned to phase $\mathrm{V}$ of this site. The results of this analysis show that the midden material was continuously used as fertilizers during this phase. The noteworthy amount of burnt material (e.g. burnt wood, burnt carbonates, rubified iron nodule, few ashes) demonstrate that burning practice was common, and agricultural soils were raised by ashes. This study indicate that Bronze Age farmers have used fertilizers to increase the agricultural production.
\end{abstract}

Keywords: Bronze Age; Arable soils; Manuring; Sandy horizons; Midden material; Micromorphology; Fertilizers; Arable land; Burnt carbonates; Amelioration; Cultivation plots; Limestone; Sandy ridges; Solifluction; Archaeology

\section{Introduction}

The Human populations were increased tremendously due to the mid Holocene climatic amelioration [1,2]. The early agricultural societies faced severe challenges to provide adequate food supply for the growing populations. Therefore, the prehistoric farmers overcome from this challenge either by increasing arable production by the expansion of arable land, or by intensifying production on land already under cultivation [3], or by crop rotations, or by using several types of fertilizers [4-8]. The usage of fertilizers is not only improving crop yields, about also helps preventing soil deterioration [9]. Furthermore, the manuring and fallowing practices are labour intensive, which also influenced daily lives of prehistoric farmers. Therefore, the study of usages of fertilizers in prehistory has been the subject of many archaeological investigations during the last decades concentrating on antiquity, natures and intensity of manuring in prehistoric farming's [10-17]. Various scientific techniques are employed to investigate these arable soils for analysing the nature of fertilizers. These techniques includes: micromorphology, soil lipid analysis [17], phosphate analysis [12], the stable isotope analysis $[15,18]$, etc.

The main aim of this paper is to identify the arable soils at the Bronze Gwithian settlement using micromorphology. It also aims to identify distinct types of cultural material added in the arable soils. Further, it also aims to make distinction between animal dung and domesticated waste and how these manuring practices change through time during the Bronze Age? It also 
aims to detect the evidences of tillage and ploughing within arable soils. Moreover, it also aims to test hypothesis if the sand horizon 602 (layer4) is a blown sand and that has been stabilized through the addition of midden material? Moreover, it also aims to investigate if the context 606 was used for agricultural activity or was it a neglected area? Initially, this paper discussed various methods used by ancient farmers to increase the soil fertility. Later, the methodology and results of this research are discussed.

\section{Soil Selection}

The nature and intensity of early agriculture in Europe is highly debatable. It is argued that the Neolithic agriculture was initiated within small farms in temporary clearing by swidden or slash and burn systems [19-21]. Moreover, the soil nutrients were maintained either by the selection of soil type (preferred ancient soils) and large-scale shifting agriculture or crop rotation or practice of intentional manuring $[4,22,23]$. Shifting model was very popular for Neolithic farming [22]. However, the archaeobotanical results from Neolithic sites in western loess belt (especially in Germany), the alpine Foreland from (c. 5500-2200 BC) and the Hungarian Plains suggests a sedentary model. Cultivation plots tends to be permanent, and which were used for extended period such as decades or centuries [24], thus ruling out concept of shifting agriculture. The arable soil fertility was maintained by choosing fertile soil.

Therefore, soil selection might be an important aspect for high crop yields. In Britain, Neolithic farmers chose the lighter soil such as those of chalk, the oolite and carboniferous limestone. They have also selected glacial-fluvial gravels, river terraces, blown sands (e.g., Pitnacree in the Perthshire in UK), the raised beaches around the northern coast of Britain, and in north east Scotland of the lighter soils [25] for agricultural farming. Sandy ridges within peat areas were chosen by the Neolithic and Bronze Age farmers in the Drenthe region [26], and Wetlands of west Friesland [27] in Netherlands (e.g., Bornwird a late Neolithic site) [28]. Moreover, the sandy areas within the midden were the choice of Neolithic, Bronze Age and Iron Age farmers in Northern Isles of Scotland and England. However, heavy soils or soils with impeded drainage were also used for agricultural practice during the Neolithic period, in the case of Anglesey in Britain [29]. The preference of prehistoric farmers for light soils relates to properties for soil themselves such as their case of tillage of pasture, rather than characteristics of natural vegetations [25]. Here, it can be argued that the soil selection for prehistoric farmers were not a matter of choice, however it was a matter of availability of soil types in the locality. They increased the fertility of arable soil by using several types of fertilizers. In prehistoric agricultural system, the fertility of arable soils was also sustained by adding domestic waste, bracken, sea-weed, animal manure, human manure, turf based plaggen material, shell sand and usage of mud etc. The next section describes these materials used for prehistoric manuring.

\section{Domestic Waste}

Domestic wastes (e.g., pottery, animal's bones, fish bones, ashes, midden material, shell sand, plant remains, animal dung, etc.) ware predominately used in prehistoric farming as a fertilizer as early as the Neolithic. Domestic wastes were recorded from the Neolithic arable soils at Bornwird in northern Netherlands [28], arable Neolithic soils in Hazleton North long cairn in Gloucestershire in UK [30], Neolithic arable soil sealed below a borrow at Strathallan [31], Neolithic soils at Tofts Ness, Sanday, Ornkey, Old Scatness [4,5], and anthropic sediments associated with Neolithic village at Skara Brae in Ornkey [14]. The records of domestic waste are also reported from Bronze Age Sandy ridges in West-Friesland in the Netherlands [32], Rantum and Archsum-Melenknof at the Island of Sylt [33], a buried Bonze Age soils at Zura [34], and early and middle Bronze age soils at Skaill at Deerness [35].

The cases-studies regarding prehistoric manuring practices from Northern Isles of Scotland and England demonstrate that midden heaps were not only ploughed insitu, but it was also intentionally disbursed over the fields during Neolithic, Bronze and Iron Age. The examples of the Neolithic midden cultivations in UK are from Pool, Sanday, Orkney [36], Tofts Ness or Old Scatness, Shetland, Skara Brae [14], Noltland, Westray [37], and Hazleton North, Gloucestershire [38]. It is suggested that the Neolithic farmers did not only cultivated earlier midden, probably created during the Mesolithic period, but they have also used those from their own creations [39]. The examples are from Northton, Harris, in the Outer Hebrides [39] and a Mesolithic midden located near Prestatyn, on the north coast of Wales, also appears to have been cultivated in the Neolithic.

The Bronze Age and Iron Age farmers (from Old Scatness in Shetland and on several sites in the Western Isles) also continued to cultivate the midden for manuring practices. The examples are from Cill Donain, South Uist [40], Baleshare, North Uist, Hornish Point, South Uist [41] and Hallshill in Northumberland, England [42]. The intensive cultivation of middens in UK during Neolithic, Bronze and Iron age at Old Scatness, Shetland. The domestic waste and cultivation of middens in prehistory were not only used as manure, but it was also used to stabilise the sandy soils.

\section{Animal and Human Manure}

It has been claimed that animal manures were probably not widely used as fertilizers in Britain until the Iron Age, when domestic livestock were kept more intensively, and dung would have been easier to collect [43]. However, the stable isotope analysis of charred cereals and pulses from 13 Neolithic sites (dating ca. 5900-2400cal B.C.) across Europe (from Greece, Germany, Bulgaria, Hungary, Denmark, and UK) demonstrate that early farmers used livestock manure and water management to enhance crop yields. More examples for the usage of animal dung as fertilizer are from a waterlogged Neolithic field in Weier, 
Switzerland [44], from the Neolithic Céide Fields, Belderrig, and Rathlackan fields in County Mayo, Republic of Ireland the Bronze Age arable soils at Toft ness in UK, a middle Bronze Age barrow in Germany on the Island of Sylt (Blume and Kalk, 1986), Bronze Age soils from Drenth region in Netherlands [45], bovine manure in the Bronze Age soil at Belderrig in Ireland, and from a Bronze Age agricultural soil in West Jutland, Denmark [46].

Lipid analysis from archaeological sites were used to distinguish between animal manure and human manure (night soils). The lipid analysis shows that large quantity of nightsoils are recognised from Bronze Age soils at Tofts Ness, Sanday, Ornkey in UK [47]. This may refer to large scale usage of human manure in prehistoric farming in UK. However, the evidence of usage of human manure in prehistoric farming are rare.

\section{Bracken}

Bracken is rarely used as a compost in early prehistoric farming. The early usage of bracken is reported from Neolithic soils excavated between two stone circles at Machrie Moor and the investigator of this site describes that bracken was first brought to the site and later it was ploughed. Whittington informed about practices of Bracken and club moss as fertilizers at Bronze Age structure within an enclosure at Cùl à Bhaile, Jura in Western Isles.

The Site of Gwithian: Archaeology and Geology

\section{Sea Weeds}

Sea weeds contains nitrogen and potassium [48], which enhances fertility and aggregate stability of soils. They become valuable fertilizers for sandy soils because of their properties. Haggarty [49] described addition of algal spores within Neolithic soils at Machrie Moor. He interpreted this as use of sea weed for manuring. A Late Bronze Age buried soils at Gwithian also demonstrate the evidence of sea weed [10].

\section{Shell Sand and Mud}

The nutrients value of arable soils was maintained by additions of shell sand mud sands. Bakels [10] reported the practice of mud from the Middle and Late Bronze Age fields near the town of Haarlem in the Netherlands. The arable soils are dark-brown in colour and formed a marked contrast with the yellow of the subsoil and layer of the drift sand. Based on the soil colour, Bakles suggested that the Bronze Age farmers may have irrigated their crops in summers and may manured their sandy field with mud from the nearby swamp [10]. Such practices were common in Netherlands until recently [50]. The practice of addition of shell sand to acid soils was not common until early first millennium AD in Ireland and the late 14th century in UK [51]. To my knowledge, shell sand was not used as manure in British prehistory.

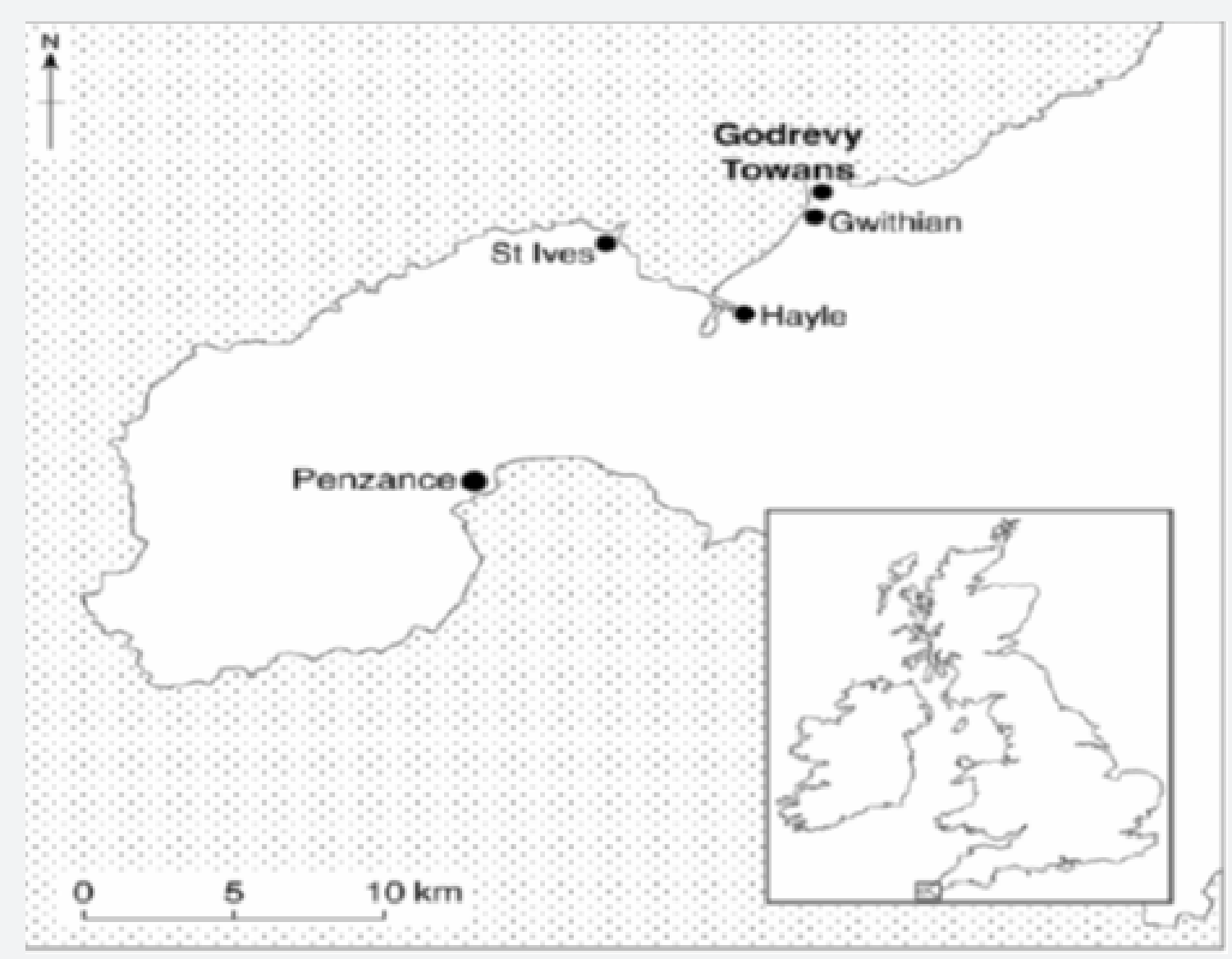

Figure 1: Location of Gwithian in Cornwall in UK (after Nowakoski, 2005). 
The archaeological site of Gwithian $\left(50^{\circ} 14.068^{\prime} \mathrm{N}\right.$ and $5^{\circ}$ $23.904^{\prime}$ W) is located on the western side of St. Ives in Cornwall

(Figure1). The stretch of coast between St. Ives Head and Trevose Head is relatively straight, with high cliffs and rocky headlands and a high proportion of coastal sand dunes. The geology of this region is comprised of sandstones, shales, conglomerates, (Old Red Sandstone) slates and limestones, which are assigned to Devonian (345-395 Ma BP) in age [52]. It is dominated by (section between St Ives and Newquay) the Porthtowan formation, which consists of slates interbedded with sandstones and siltstones. The outcrops at Black Cliff near Hayle, and again north-east past Godrevy Point, and between Porthtowan and Perranporth are characterised by this formation. It is interesting to notice that Cornwall were not glaciated during Pleistocene (between 2 million and 10,000-year-old). Therefore, the landscape of this region is dominated by Pleistocene periglacial deposits, which are categorised into raised beach deposits, and head deposits. The raised beach sediments (near Godrevy on the eastern side of St Ives Bay) are assigned to Godrevy Formation, which were deposited during the high sea level phase of the Ipswichian interglacial [52]. The main constituents of head deposits in this region are unconsolidated and poorly sorted sediments, originated by freeze-thaw and slumping/solifluction during glacial periods between 75ka BP and 25ka BP [53]. Periglacial deposits are variable in nature, being composed of varying proportions of sands, gravels, boulders and muds. The study area has a substantial proportion of hindshore and sand dunes. These dunes, such as at Phillack to Gwithian Towans, Godrevy Towans, Penhale and Holywell, develop to some considerable distance inland above beaches develop in sediment-rich areas under strong onshore winds.

The main geographical characteristics of the study area are wind-borne sand and the fluctuations of the shore-line around an ancient estuary [53], which played significant role for the cultural development in the study area. These were mainly in a sloping meadow to the north of the Red River, about $800 \mathrm{~m}$ inland from the modern coastline. Initially, Mesolithic flits were discovered over a wide area [54], however the full archaeological potential of the Gwithian site came into existence after the excavations led by Professor Charles Thomas from the late 1940's to the 1960's. Later, an interdisciplinary research project was also started at Gwithian in 2005-2007, under the supervision of professor Charles Thomas, for the complete assessment of the results of two major unpublished excavations which took place in West Cornwall during the 1940's and 1960's.

The special alkaline qualities of the sand have ensured the survival of a rich range of organic (except for pollen) materials and the survival of former land surfaces comprising well stratified sequences from the prehistoric and postRoman periods. Five phases of Bronze Age (from c. 1800 to c. 900 cal. BC) occupations were recognised from the section of GMXVII at Gwithian, each separated by win blown sand (Table 1). In addition to the settlement, the evidence for prehistoric cultivation with the stone walled fields, surviving imprints of ard marks and spade marks within fields, alongside structures and burials dating to the 2 nd millennium BC are also reported, which provides a unique story for the British Bronze Age. Moreover, records of a Roman homestead were also reported from area near to Godrevy Headland. A sand dune nearby Bronze Age site provides remains of a post-Roman settlement with industrial and agricultural activity, which was dated from 5 th to 8th centuries AD. The results of this excavation have never been published, however a recent un published report provides a comprehensive summary of the work [1].

Table 1: Showing, layers, context numbers, field descriptions of layers, locations of micromorphological samples, cultural periods, chronology, and occupational areas mentioned in this texts.

\begin{tabular}{|c|c|c|c|c|c|c|}
\hline $601(=3)$ & $\begin{array}{l}\text { Buried Bronze Age plough soil with ard } \\
\text { marks at the base (10 YR } 4 / 3)\end{array}$ & $\begin{array}{l}\text { G1, } \\
\text { G2 }\end{array}$ & $\begin{array}{l}\text { Middle/Late } \\
\text { Bronze Age }\end{array}$ & c $1300-900$ cal. BC & Phase 5 & $\begin{array}{l}\text { settlements and } \\
\text { fields }\end{array}$ \\
\hline $602(=4)$ & $\begin{array}{l}\text { Wind-blown pale brown sand (10 YR } \\
6 / 3) ; 3 \text { distinct layers. ard marks at the } \\
\text { base cut into layer } 605 \text {, below. }\end{array}$ & $\begin{array}{l}\text { G3, } \\
\text { G4, } \\
\text { G9 }\end{array}$ & $\begin{array}{l}\text { Middle Bronze } \\
\text { Age }\end{array}$ & $\begin{array}{c}\text { c } 1500-1200 \mathrm{cal} . \\
\text { BC }\end{array}$ & Phase 4 & $\begin{array}{l}\text { fields, traces of } \\
\text { midden used as } \\
\text { fertilizers }\end{array}$ \\
\hline $605 b(=5)$ & $\begin{array}{l}\text { Buried Bronze Age plough soil withs ard } \\
\text { mark at the base and the surface. This } \\
\text { context probably represents } 2 \text { layers, } \\
\text { Sandy loam horizons (10 YR 5/3) }\end{array}$ & $\begin{array}{l}\text { G4, } \\
\text { G5, } \\
\text { G6 }\end{array}$ & $\begin{array}{l}\text { Middle Bronze } \\
\text { Age }\end{array}$ & $\begin{array}{c}\text { c } 1500-1200 \mathrm{cal} . \\
\text { BC }\end{array}$ & Phase 3 & $\begin{array}{l}\text { stone and post built } \\
\text { structure associated } \\
\text { with terraces and } \\
\text { several phases of } \\
\text { ploughed field }\end{array}$ \\
\hline $606(=6)$ & $\begin{array}{l}\text { Light yellowish-brown sand (10YR 5/4)/ } \\
\text { single banded horizon of wind-blown } \\
\text { sand }\end{array}$ & $\begin{array}{l}\text { G6, } \\
\text { G7 }\end{array}$ & $\begin{array}{l}\text { Early to Middle } \\
\text { Bronze Age }\end{array}$ & С $1800-1500$ BC & $\begin{array}{l}\text { Phase } 2 \text { to } \\
\text { Phase } 3\end{array}$ & $\begin{array}{l}\text { neglected area with } \\
\text { some ard marks }\end{array}$ \\
\hline $608(=7 a)$ & $\begin{array}{l}\text { Yellowish brown sand, ard marks on top } \\
\text { of this horizon }\end{array}$ & $\begin{array}{l}\text { G7, } \\
\text { G10 }\end{array}$ & Early Bronze Age & c. 1800 cal. BC & $\begin{array}{l}\text { Second Sub } \\
\text { phase of Early } \\
\text { Bronze Age }\end{array}$ & $\begin{array}{l}\text { homestead and } \\
\text { farming }\end{array}$ \\
\hline
\end{tabular}


Recently, a multi-proxy analysis was also conducted on sediments from coring and test pits around the settlement sites in Gwithian. The aim of this analysis was to investigate when sand dunes initially developed in the red river. This study provides a detailed summary of environmental conditions, human influence for changing the landscape, and chronology for environmental and cultural changes during the Neolithic period.

\section{Research Methods}

Thin section micromorphology is applied to identify the material used to increase the soil fertility for arable soils, and to identify the geogenic, biogenic and anthropogenic process though which these soils were formed. Dr. Erika Guttmann Bond, my mentor for this research, participated in the field work,

Results and Interpretations which was started in 2005-2007. Dr. Guttmann collected 15 undisturbed soil samples using Kubina tins from GMXVII site of Gwithian (Figure 2) (Table 1). Further, thin sections slides were manufactures by drying, impregnated with resins under the reduced conditions. Dr. Guttman has provided me 15 slides to conduct this research.

A polarising microscope was used to study the thin sections and interpreted using the international system for thin section description provided by Bullock et al. (1985) and Stoops et al. (2003). A variety of magnifications (x10 - x400) and light sources (plane polarised, cross polarised and oblique incident light) were used. The interpretations are also based on Fitzpatrick \& Courty et al. [55,56]; quantifications were made by consulting an abundance chart [57].

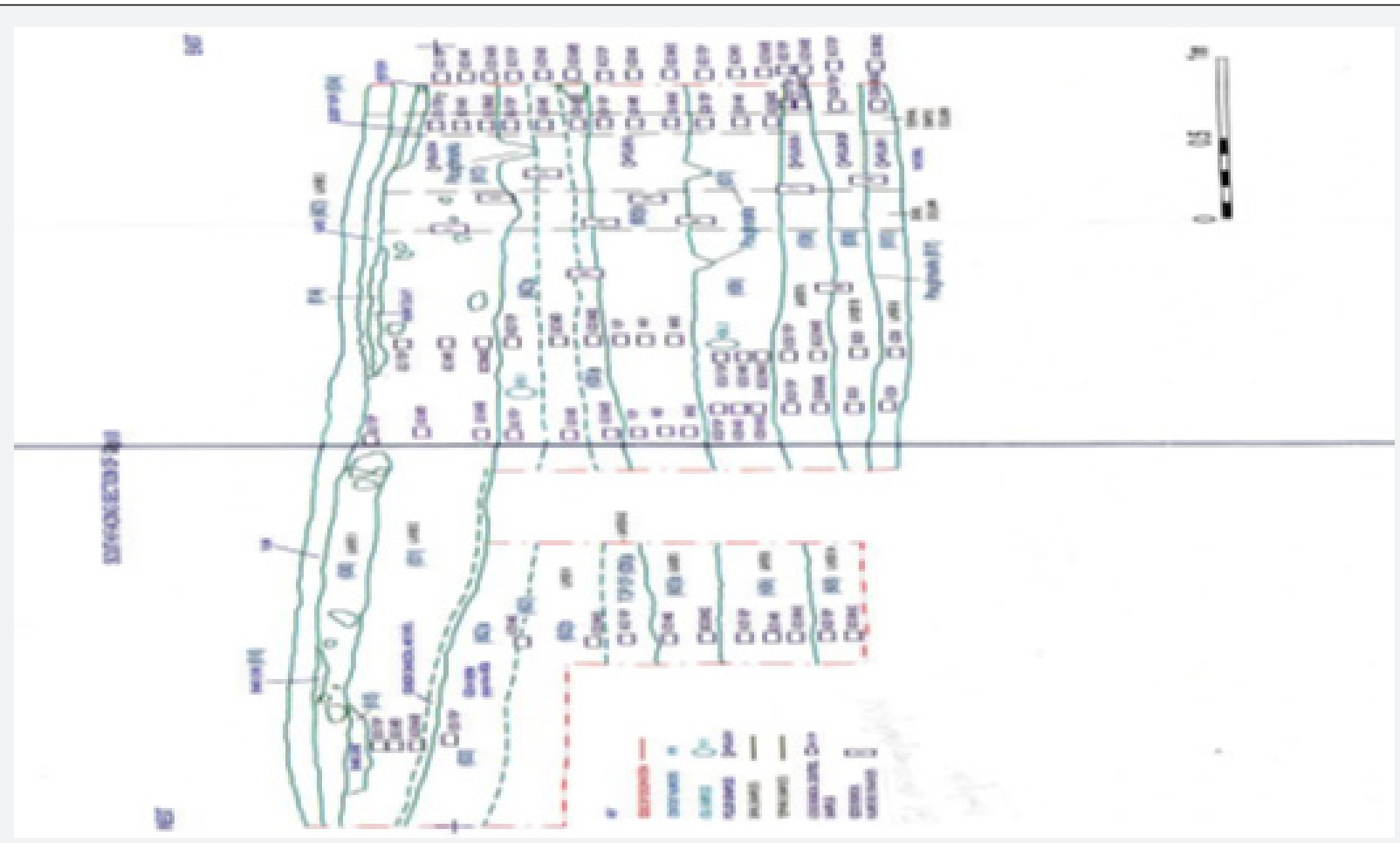

Figure 2: Describing the layers, context numbers and locations of micromorphology samples described in this text (after Nowakowski et al., 2007). 


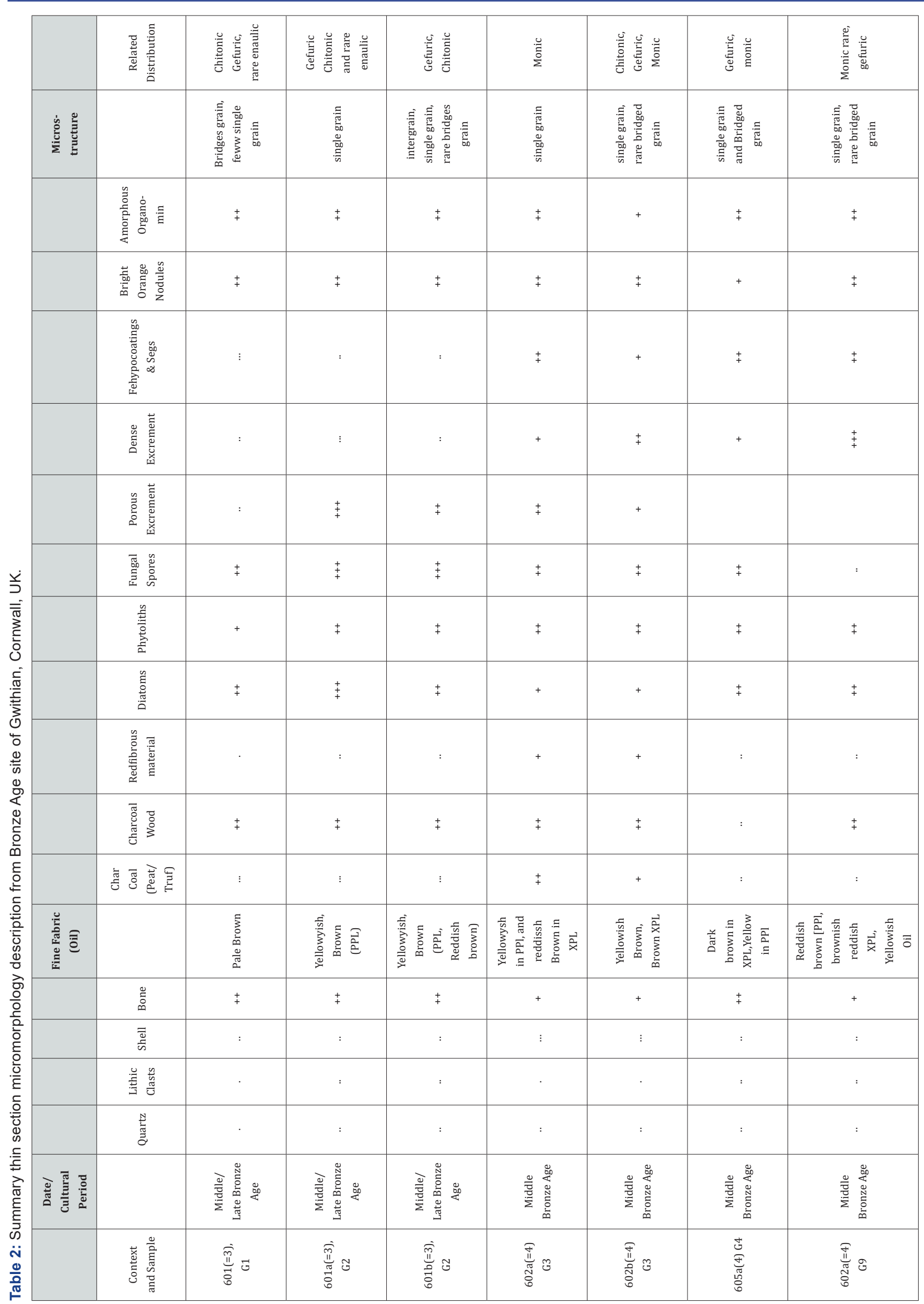




\begin{tabular}{|c|c|c|c|c|c|c|}
\hline 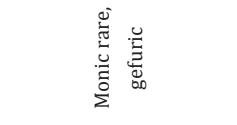 & 䒬 & 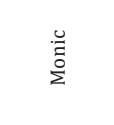 & 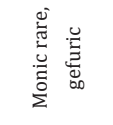 & 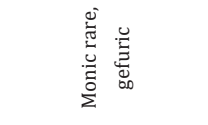 & 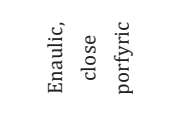 & 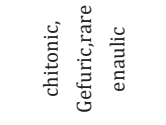 \\
\hline 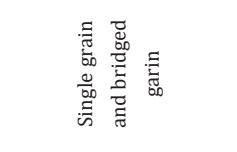 & 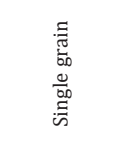 & 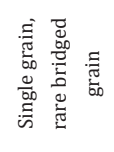 & 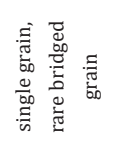 & 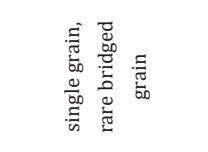 & 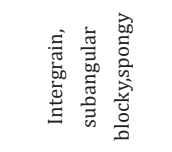 & 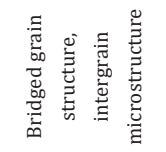 \\
\hline & + & $\ddagger$ & : & $\ddagger$ & $\ddagger$ & 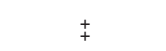 \\
\hline & + & + & + & $\ddagger$ & : & : \\
\hline : & + & $\ddagger$ & $\ddagger$ & $\ddagger$ & $\vdots$ & : \\
\hline : & + & \pm & $\ddagger$ & $\ddagger$ & $:$ & $\vdots$ \\
\hline & 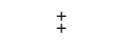 & 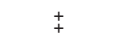 & : & + & + & $\underset{+}{+}+$ \\
\hline : & + & + & + & $:$ & : & : \\
\hline+ & $\mp$ & + & + & $\ddagger$ & $\ddagger$ & + \\
\hline 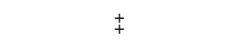 & + & & + & + & $\ddagger$ & $\stackrel{+}{+}$ \\
\hline$\ddagger$ & + & $\mp$ & $\ddagger$ & : & : & $:$ \\
\hline$\ddagger$ & + & & $\ddagger$ & : & : & : \\
\hline+ & $\ddagger$ & & $\ddagger$ & : & : & : \\
\hline 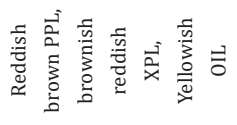 & 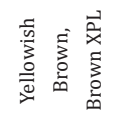 & 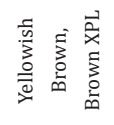 & 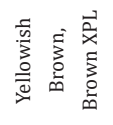 & 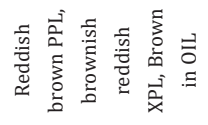 & 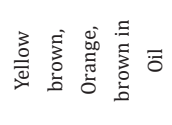 & 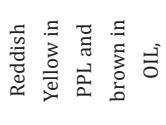 \\
\hline$\stackrel{+}{+}$ & & & $\stackrel{+}{+}$ & $\ddagger$ & + & + \\
\hline$\vdots$ & & : & : & : & . & $:$ \\
\hline : & : & : & : & $:$ & : & . \\
\hline : & : & & : & : & : & : \\
\hline 竞 & 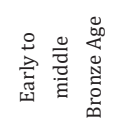 & 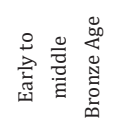 & 在总 & 갈 & 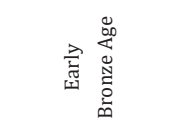 & 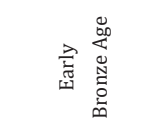 \\
\hline 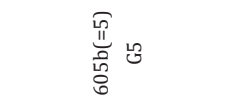 & 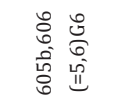 & 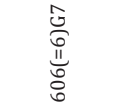 & 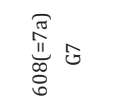 & 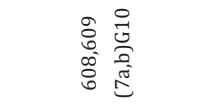 & 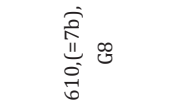 & 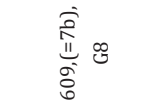 \\
\hline
\end{tabular}


The layers, context numbers, field descriptions of layers, locations of micromorphological samples, cultural periods, chronology, and occupational areas mentioned in this text are described in Figure $2 \&$ Table 1 . The summary of thin section analysis is described in Table 2 .

Thin section G8 is taken from the interface of context number 609 and 610 which is equivalent to layer 8 and layer $7 \mathrm{~b}$ (Figure 2). These layers belong to phase 1 of early Bronze Age occupations and it is dated as c $1800 \mathrm{cal}$. BC. The layers 7 and 8 are characterised by occupation area, which shows evidences of Bronze Age settlement and field area. Evidence of plough marks are reported from the layer 8 of this site [1].

The results of thin section (G8) analysis (610=layer 8) shows that the microstructure is in the combination of sub angular blocky structure, fissure structure, and intergrain micro aggregate structure. The sub angular blocky structure is formed because of wetting and drying or freezing and thawing or faunal activity [55]. The related distribution is enaulic, chitonic and close porphyric. The pedal structure is mostly prism, sub angular blocky peds. The peds are moderately developed and accommodated. The prismatic structure is found, which show that soils are formed due to the ploughing practices [58].

The distribution pattern is characterized by mostly by channels, vughs, compound and packing voids, and rarely cracks. Horizontal planar voids and channel space are moderately high (20\% of slide area). The presence of planar voids and channel structures is interpreted as indication of ploughing [59-61]. However, channel formation is also ascribed to the movement of soil animals such as earth worms or the growth and infiltration of roots. Moreover, phases of wetting and drying are considered the primary factors leading to the development of planar voids in temperate soils, particularly those containing significant amounts of expandable clay minerals [62]. Vughs may also results from several different mechanism including faunal activity, differential solution of mineral grains, irregular packing voids having a wide range in particle size distribution [63], incomplete infilling of packing voids by translocated clay from upper horizons or deformation of other voids by faunal, freeze/thaw or shrink, swell pressures. Genies of complex and compound packing voids is less easy to formulate, although one or a combination of packing, faunal (e.g., earth worm) movement or excretion and shrinking/swelling due to changes in moisture regime may be responsible in some examples [63].

Bones fragments are noticed, which has porous structure. It is yellowish in PPL and black in XPL. Populations of fine material is also identified, which is yellow in (PPL) and black in XPL, indicating phosphatic origin of fine material. This evidence suggests that the yellow material in PPL (black in XPL) is comprised either of decayed plant material or herbivorous dung. The course organic material is made of fragments of charred materials $(300 \mu \mathrm{m})$ and woody charcoal. Iron segregation and accumulation of iron on mineral and soil are also noticed.
Rubified iron nodules $(1200 \mathrm{~mm})$, rubified fibrous organic material (orange in OIL) surrounded by fine organic material, and few burnt woods are also noticed. Some elongated grass charcoal fragments are also identified, which are black in PPL and XPL. This charred material also contained ash particles, which are grey in PPL and dark grey in XPL. This indicates that fire activity was taken place in the area or they were intentionally added in soils by the farmers.

The intimate mixing of clays, silts, and organics is noticed, which suggests biological activity was once important, resulting in homogenization of the soil matrix. However, as excremental features are also noticed. The presence of typic iron nodules, sometimes within aggregates, and the zones of iron and clay depletion around the edges of macro voids are also noted. Thin clay coatings were identified in the soil voids. The presence of clays coating and darkened by organic material are interpreted for tillage activity $[64,65]$. Such features should be interpreted carefully because they might be resulted due to natural processes $[66,67]$.

Thin section G8 (context 609-layer 7b) analysis indicates microstructure has mostly bridged grain structure and rare occurrence of pellicular and areas of porphyric at the base of thin section, with mostly gefuric (also monic) related distributions. This means that it is sandy and freely drained and has also clayand silt-sized material to make the soil cohesive. The fine fabric is reddish brown in PPL, brownish reddish in XPL and brown in OIL, resulted due to fire activity. Moreover, this fine fabric also contained small particles which is grey in PPL and dark grey in XPL, indicating a high component of ash [68-70]. Some areas of fine material with yellowish brown in PPL and black in XPL is also recognised, resulting either from decayed plant matter or herbivore dung.

The pedofeatures are identified in the form of iron accumulation on the sand grains. Iron nodules of $30 \mathrm{~mm}$ are also noticed. Rubified iron fibrous nodule surrounded by organic material is also identified. The edges of fine fabric are round; it means that compacted earth worm excrement. Link capping of fine fabric of grains are also identified. Mostly discontinuous fine fabric is noticed on the grains. Decalcification of shell is also noticed. The striking colour suggests that the earliest soil was composed almost entirely of organic material. The particle- size distribution of this layer was distinctly finer than that of the later soils and was like the silt-size material that made up the sample G7. Inclusion of organic material in excremental pedofeature is also identified, which indicate to tillage activity, however such pedo-features are also developed due to bioturbation as well.

Thin section G10 was taken from the interface of layer $7 \mathrm{~A}$ (context 608) and layer 7 B (context 609). This sample belonged to second sub phase of early Bronze Age (Figure 2) (Table 1). Thin section analysis indicates main difference between context 608 and 609, which is described through sample G10. 
At context 608, mineral grains are single grain structure and they are coated with fine fabric and few clay coatings around the grains; whereas grains and aggregates are surrounded by clay mineral in context 609 of sample G10. The microstructure is mostly single grain structure and occasionally very rare bridged grain structure in context 608; where as it is mostly bridged grain structure and inter grain channel structure in context 609 . The related distribution is monic and very rare gefuric in context 608. But, the percentage of gefuric related distribution in context 609 is very high.

The porosity is characterized by simple packing voids in context 608 and compound packing voids, complex packing voids and channels are main characteristic in context 609 . Occasionally, vughs, chambers vesicles and planar voids are also identified. The planar voids are interpreted as the indication ploughing; however, these structures may be replaced by channels in the spring. Rare occurrence of bones is also noticed. The fine fabric is low birefringence. It is reddish brown in PPL, red in XPL, and brown in OIL, resulted due to fire activity. These fine fabrics also contained abundant particles that are grey in PPL and XPL, interpreted as ash residue. Thin monomorphic organic material coating around the sand grains are identified.

Many evidences of charred wood with plant tissues (e.g., s1000mm in size) are identified, which indicates usages of domestic waste as manure, originated from fire activity. Moreover, fragments of amorphous uncarbonized material with quartz grains, rich in organic matter, is also identified, which interpreted as residues of midden material. Similar evidences of midden material were also evidenced from prehistoric arable soils from Kailyard areas, Papa Sour, Shetland Isles [71]. Phytoliths are also identified, which indicates for usages of herbivores dung as fertilizers. The diatoms probably derive from grasses, which might have brought from middens and used for fuel. Dusty clays are also identified, which indicates for ploughing signature.

The Pedofeatures are characterized by red typic nodule of $200 \mathrm{~mm}$, accumulation of iron on grains, decalcification of shell, very rare depletion of iron and almost all the grains have continuous clay coatings. Several types of excremental fillings are also identified. Such excremental features sounded by fine organic material are formed due to tillage activity [72]. Clayey silt or silty clay pedofeature and layered coating around packing voids are also identified. Area of compound layered textural coating, including micro laminated clay, silt and limited clay are identified. Such clayey pedofeatures are formed due to tillage activities [64,65].

Sample G7 belonged to the second sub phase of Early Bronze Age horizon. This sample is taken from the interface of context 608 (layer 7A) and 606 (Layer 6). Layer 7 was identified as a cultivation horizon during fieldwork in 2005 at site GMXVII, which was located down slope from GM/XV (Figure 2). Mostly single grain structure is noticed in 606; whereas very rare pellicular and much bridged grain structure is also noticed in 608. There is rare fine fabric in context 606 of G7. The related distribution is monic in both contexts (606 and 608). Gefuric related distribution is identified from context number 608 . The grains are rounded sub rounded in size. The fine fabric is yellowish brown in PPL, brownish yellow in XPL, and yellowish in brown in OIL and low birefringence. Coarse organic is comprised of very rare charred wood. The main constituents of fine organic material are few glassy yellow materials and phytoliths with inclusion of silt, which indicate practice of dung as fertilizers. Iron depletion must have taken place before deposition as the acidification process required to form them would not have occurred in the calcareous depositional environment. Phytoliths are also noticed, suggesting a grass based organic input. Pedofeatures are characterized by iron accumulation and depletion on the grains, decalcification of shell on the corner of the shell grains and sometime in the centre of the shell, continuous fine material coating on the mineral grains is context 608 , whereas context 606 has rare discontinuous fine fabric and clay coating on grains.

Traces of limpified clay within planar voids are also noticed, which indicate tillage activity. Rubified iron nodules with fibrous organic material (orange in OIL) are also identified, which describe usage of fire activity. The size of rubified iron nodules are ranging between $3 \mathrm{~mm}$ to $900 \mathrm{~mm}$. Accumulation of yellowish material is noticed on the grains. It is yellowish brown in PPL and black in XPL. Organic fine material is also noticed, the bulk of which can be described as amorphous at this magnification; some cell residues are easily recognizable. The yellowish fine material indicates phosphatic nature of soils. Nearly colourless zones are little decomposed, intense yellowish to reddish brown zones are moderately, and low chrome bright to mahogany brown and opaque zones highly decomposed. Depletion coating is also identified where iron has been removed from a zone around a channel. Yellowish brown needle like cell structure is identified. Comminution by oribatid mites has been transformed the organ residue (needles) directly into cell fragments, the yellowish-brown material are residues of cell content.

Sample G6 was taken from interface of layer 6 and layer 5 (605b) (Figure 2). Layer 6 belongs to phase early to middle Bronze Age. It is represented by a single banded horizon with few ard-marks and the field report indicates that it is described as a layer of clean wind-blown sand. Field observation suggested that Bronze Age neglected this area for farming (Table 1) [1]. Layer 6 belongs to Phase III of Middle Bronze Age, dated as c 1500-1200 cal. BC. Thin-section analysis shows that there is no major difference between these two layers. The microstructure is mostly single grain structure. The distribution pattern is comprised $80 \%$ simple packing voids and 10\% channels and chambers. The related distribution is monic. The grains are sub rounded and angular in size, with sub rounded shell fragments. 
The fine fabric is yellowish brown in PPL, black in XPL, yellowish brown in OIL and it has also low birefringence, which is interpreted as organic/anthropogenic origin of soils. Few traces of porous material are identified, which is interpreted as bone. There was no signature of wood material, no charcoal and no charred material. The fine material is comprised of very rare fungal sclerotia. Pedofeatures made of few iron nodules $(100 \mathrm{~mm})$ accumulation of iron on grains, very rare occasional discontinuous fine fabric on grains, no clay coating on grains.

Sample G5 is a sandy loam and it was taken from context $605 \mathrm{~b}$ (layer 5) and it belong to phase III of middle Bronze Age, dated as c 1500-1200 Cal BC. Thin section analysis shows single grain microstructure and occasionally bridged grain structure. The single grain structure usually inherited from the parent material; removal of fine material from vertical leaching or lateral differential emotional, and the genesis bridged grain structure is because of deposition of concentration of silt and/ or organic matter around sand grains. The distribution pattern is mostly marked by simple packing voids and very rarely by complex packing voids. The related distribution has mostly monic and occasionally gefuric. The porosity is made up of $40 \%$ simple packing voids and very rare occasional channel. The grains population is mostly angular, and sub rounded, and it has $15-20 \%$ quartz, $10 \%$ shell, and very rare population of mica and feldspar. Organic material is yellowish brown in PPL, greyish in XPL, and brown in oil. Few traces of bones are identified.

Wood material, ashes, or charred wood are rarely found this section. Very rare fungal sclerotia is noticed and yellow material is also noticed which is interpreted as organic material. The main characteristics of pedofeatures are made of iron nodules $(400 \mathrm{~mm})$. The iron nodule is reddish brown in PPL, brownish red in XPL. Very rare depletion and accumulation of iron on grains is noticed. Very rare discontinuous fine fabric is also observed from this thin section. Decalcification of shell is also an important pedofeature. Some soil aggregates contain excremental and textural pedofeatures, characterised by presence of black carbon particles, indications of practice of organic material as manure [73], however these pedofeatures also created by biological and natural soil activities.

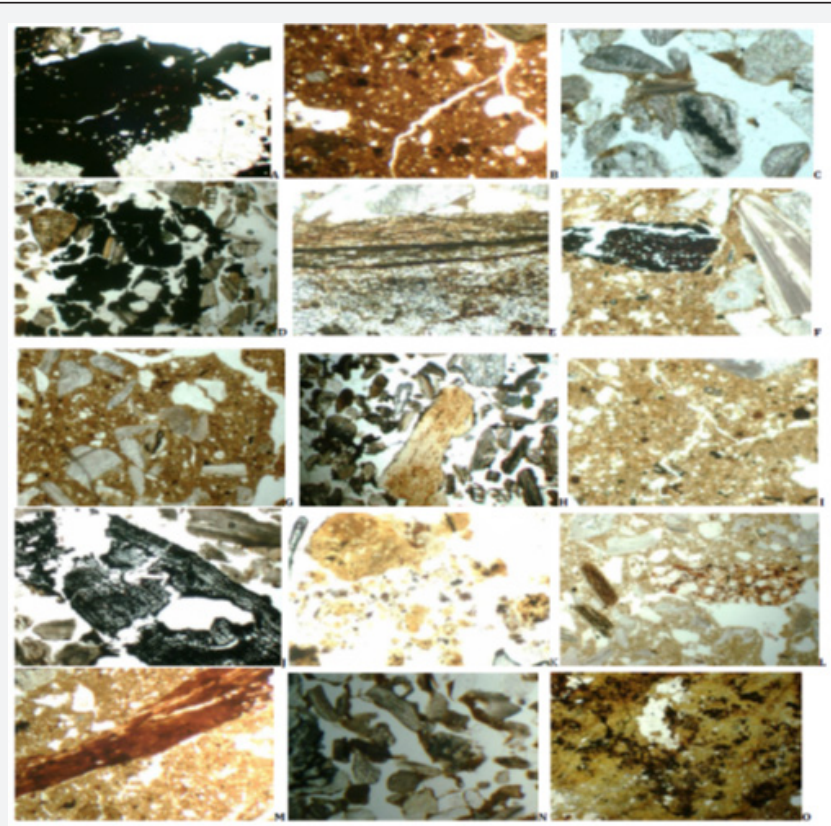

Figure 3: Micromorphological features from Bronze Age site of Gwithian in Cornwall, UK:

a. Decomposed wood with original tissue structure.

b. Rubified fabric with fine organic material indicative of fuel residue, with channel structure.

c. Grains aggregates with thin clay coatings.

d. Decomposed wooden material with bones.

e. Decomposed wood/root lying horizontally on floor.

f. Burnt wood material with original tissue structure, tree trunk with its rings and ash particles.

g. Sand grain aggregates surrounded by clays, fine organic material and tiny fragments of charred wood.

$\mathrm{h}$. Intergrain microaggregate soil structure and bone fragment, with tissue structures

i. Planar voids with small particles of fine organic material.

j. Burnt wood with original tissue structure.

k. Quartz sand grains surrounded by fine yellowish organic material, interpreted as animal dung.

I. An example of iron depletion.

$\mathrm{m}$. Elongated iron nodules with rubified sandy aggregates,

n. An exampssle of bridged grain structure.

o. Excremental and textural pedofeatures, besides being characterised by intensive homogenisation through biological activity and by the presence of black carbon particles. 
Sample G4 was collected from interface of layer 4 (605a) and 5 (605b). It belongs to Middle Bronze Age and phase III, whereas layer 5 belong to Middle Bronze Age and phase IV. No significance differences between these two layers are identified and they are described in same context. The microstructure is single grain structure and very rare bridged grain structure. The related distribution is gefuric and monic. The porosity is described as simple packing voids and vughs and occasionally complex packing voids are also noticed. The minerals are sub rounded, rounded and angular. The mineral population is comprised of $15 \%$ quartz, $2 \%$ lithic clasts, $10 \%$ shell fragments, $15 \%$ minerals including feldspar, v. rare chlorite, and rare earth worm granules are also observed. There are two population of fine fabric is noticed. The first population of fine fabric is brownish yellow in PPL, reddish brown in XPL, black in OIL. The second population fine fabric is constituted of yellowish brown in PPL, black in XPL, yellowish brown in OIL, indicating presence of decomposed organic material. Yellowish glassy feature is also identified, which is interpreted as decomposed bone. The main component of coarse organic material is wood material $(600 \mathrm{~mm})$, and charred wood $(1000 \mathrm{~mm})$ with tissue structure, and charred plant fragments. Few diatoms and phytoliths are also identified. The diatoms probably derive from grasses taken from the uplands for fuel. The fine fabric has very rare fungal sclerotia and very rare phytoliths. The main constituents of pedofeatures are iron nodules (bright red in PPL) segregation and strongly impregnated typic nodules, $2 \mathrm{~mm}$ wood or charcoal, very rare mineral grains coated with discontinuous fine fabric, indicated to fire activity. Accumulation and depletion of iron is also observed. Decalcification of shell is observed from the centre and from corners. Excremental and textural pedofeatures surrounded by organic material are also recognised, which point to practice of organic material as a manure (Figure 3).

The context for sample G9 was mainly from 605a and from stratigraphic point of view; it is described as a mixture of layer 4 (605a) and layer 5 (605b). It belongs to Middle Bronze Age, dated as c $1500-1200$ cal. BC of Phase 3 and Phase 4. Thin section description shows that there is no major difference between these two layers in this sample. Single grain microstructure is noticed and very rare, occasionally, bridged grain structure is noticed on layer 5 (605b). The related distribution is mostly monic, occasionally chitonic and very rarely gefuric is also observed on layer 5 . The porosity is characterized by mostly single packing voids and rare channel structure is also noticed. The mineral grains are rounded, and sub rounded in shape and comprised of $35 \%$ quartz, $10 \%$ shell fragments, $10-15 \%$ rare minerals including mica, feldspar, chlorite, $2-5 \%$ lithic clasts and very rare bone. Earth worm and slug granules are also noticed. The colour of fine fabric is yellowish brown in PPL, reddish brown in XPL, and brownish red in OIL. The fine fabric is also low birefringence. The course organic material is comprised of $200 \mathrm{~mm}$ charred wood, charcoal and $1.5 \mathrm{~mm}$ charred plant fragments. The fine organic is made of very rare fungal sclerotia.
The pedofeature is marked by inclusion of fine material in the typic nodules, accumulation of iron on the grains, very rare discontinuous coating of fine fabric on mineral grains, very rare iron nodules. The iron nodules are strongly impregnated and pure typic. The organic material is yellow in PPL, black in XPL, which is interpreted as decomposed material. The phase III (e.g., G4, G5 and G6) and phase IV (G3, G4 and G9) shows occurrence of excremental and textural pedofeatures surrounded by organic material, which is reddish brown in PPL, gives indication of practice of organic material as fertilizers. The abundance occurrence of midden material from these contexts indicates that farmers of this phase used middens materials not only as fertilizers, but they also used to stabilize sandy horizons. Sample G3 was taken from the interfaces of layer 3 (602a) and layer 4 (602b). Layer 4 belongs to Middle Bronze Age, dated as c 1500 - 1200 Cal BC Phase 4, whereas layer 3 belongs to Phase 5 of Middle to Late Bronze Age, dated as c 1300 - 900 cal. BC. These two different contexts are described separately.

Sample G3 602a the micro structure is mostly single grain structure, and very occasionally micro aggregates microstructure is also identified. The related distribution is monic. The porosity is characterized by $40 \%$ of simple packing voids, $5 \%$ vughs, and occasionally channels micro structure. The voids are 50 $60 \%$ of total slide. The grains are rounded, and sub rounded in shape and the total population of grains is comprised of $15 \%$ quartz, $10 \%$ shell fragments, very rare stone fragments. The fine fabric is fibrous reddish brown, very occasional yellowish brown, in PPL, dull grey in XPL, might have originated due to fire activity. But there are some fragments of yellow material which may be interpreted as organic material. The pedofeatures is characterized by a population of nodules which are $20 \mathrm{~mm}$ in size and they are yellow in PPL, yellowish brown in XPL, and brownish yellow in OIL. There is discontinuous coating of fine fabric on grains. The fine fabric is yellow in PPL, yellowish brown in XPL, and brownish yellow in OIL. The edge depletion of shell fragments is also noticed. Iron accumulation is also noticed in some shell fragments.

Sample G3 602b the related distribution is largely monic and occasionally combinations of gefuric chitonic are also noticed. The micro structure is mostly single grain structure, occasional bridged grain structure and pellicular grain structure. The porosity is made $20-30 \%$ of complex packing voids, $10-15 \%$ compound packing voids, 2-5\% channels, and 5-10 vughs. The mineral grains are angular and sub angular in shape. The population of mineral grains is comprised of $25 \%$ quartz, $0.5-2 \%$ chitonic, $5 \%$ calcite, $5 \%$ lithic clasts and $15 \%$ of shell fragments. The fine fabric is yellowish brown in PPL, reddish brown in XPL and yellowish brown in OIL. It is also very low birefringence. The course organic material is made of small fragments of charred material, and bone fragments. The fine fabric is comprised of fungal sclerotia on bone and it is in yellowish orange colour in PPL which is interpreted as organic material. In pedofeatures, activity of earth worm on granules, depletion of calcium, very 
rare fine material discontinuous coating on grains, very rare iron nodules of $200 \mathrm{~mm}$, loose discontinuous excremental infilling and $405 \mathrm{~mm}$ of bone with fungal attack is noticed. The phase III (e.g., G4, G5 and G6) and phase IV (G3, G4 and G9) shows abundant occurrence of excremental and textural pedofeatures surrounded by organic material, which is reddish brown in PPL, gives indication of practice of organic material as fertilizers. The abundance of organic/midden material in context 602 (4) prove our hypothesis that the sandy soil of this context was stabilised by midden material.

Sample G2 was taken from the meeting point of context no 601 (layer 3) and 602a (layer 4). These contexts are also described separately. Layer 3 belongs to Phase 5 of Middle to Late Bronze Age, dated as c 1300 - 900 cal. BC.

Sample G2 (601=layer 3) the microstructure is mostly intergrain micro-aggregate and very rare bridged grain structure. The related distribution is chitonic, enaulic and gefuric. The porosity is characterized by $20 \%$ complex packing voids, $40 \%$ simple packing voids, $<5 \%$ channels. The mineral grains are rounded, sub rounded, platy and tabular. The mineral population is comprised of $15 \%$ quartz, $10 \%$ shell, and very rare $\% 2$ of minerals such as schist, sand stone, schist, very rare stone fragments. Two main populations of fine fabric are identified. The first population of fine fabric is brownish reddish in PPL, reddish brown in XPL, and brownish yellow in OIL. The second population is yellowish brown in PPL, black in XPL, and brownish yellow in OIL. The fine material is low birefringence. It is interpreted as decomposed plant material. The course organic material is made of decomposed wood and charred wood $(700 \mu \mathrm{m}$ and $2000 \mu \mathrm{m})$ with original structure. Pedofeature is characterized by iron accumulation on calcium carbonate, depletion calcium on the shell fragments, $1000 \mu \mathrm{m} \mathrm{mm}$ very red typic nodules, very irregular clay and fine material coating on grains, dense incomplete excremental feature and the iron accumulation on the edges of sell fragments.

The microstructure for context $602 \mathrm{a}$ is mostly single grain, and the related distribution is monic. The voids are characterized by $90 \%$ of complex packing voids, very rare simple packing voids and very rare channels. It has mainly shell fragments and very less fine material. The rest of thin-section descriptions of context 602 are like context 601.

Sample G1 was taken context no 601 (Layer 3) and it belongs to to Phase 5 of Middle to Late Bronze Age, dated as c 1300 - 900 Cal BC. The micro structure is mostly bridged grain structure, single grain structure and occasionally inter-grains micro aggregate structure. The Related distribution is chitonic gefuric very less enaulic. The porosity is characterized by $40 \%$ complex packing voids, $29-30 \%$ channels, $30-40 \%$ chamber from voids or complex. Genies of complex and compound packing voids is less easy to formulate, although one or a combination of packing, faunal (e.g. earth worm) movement or excretion and shrinking/ swelling due to changes in moisture regime may be responsible in some examples. Channel formation is normally ascribed to the movement of soil animals such as earth worms or the growth and infiltration of roots. Associated chambers are thought to develop by faunal activity.

The mineral grains are angular to rounded, platy and tabular form, and the mineral population is comprised of $10-15 \%$ quartz, $15 \%$ substance including plagioclase, calcite, fragments of mica and schist, sand stone, spartic lime stone, $5 \%$ shell fragments, and lithic clasts $10-15 \%$ stone fragments up to $4-5 \mathrm{~mm}$. Fine Fabric is brownish yellow, (PPL), black in XPL, and yellowish brown (OIL). Coarse organic is comprised of $5 \mathrm{~mm}$ charred wood with its original structure, reddish brownish fibrous fragments of organic material (abundantly occurred in slide), $5.7 \mathrm{~mm}$ original wood, earth worm deposits, made channel-blocky voids, channel voids, yellow organic material interpreted as decayed plant material. The Fine organic material is characterized by very rare fungal sclerotia.

Pedofeatures is characterized by earth worm activity which makes channel blocky voids and sub-angular blocky structure, earth worm granules, phytoliths, there is white substance around the grain which is interpreted as depletion of calcium, decalcification of shell. Fine Fabric is continuous, internal and external hypo coating, rounded organic material, occasional discontinuous clay coating (not pure clay), link capping of grains. The colour of nodule is yellowish brown (PPL) and brownish yellow (PPL). Depletion coating: iron has been removed from a zone, very bright typic nodule interpreted as fire activity. The red typic nodule is very red in (PPL) and red in OIL. Pseudomorphic feature is interpreted from weathered material of plant fragments. Elongated thinner particle of black material, black in PPL and XPL, which is interpreted as grass charcoal. The percentage of charred wood is very high, which indicates that the Late Bronze Age farmer has used ash for manuring.

Midden material is commonly identified from the phase IV and V (Middle/Late Bronze Age), it indicates that the prehistoric farms brought organic material from a wastage heap.

\section{Discussions and Conclusion}

Micromorphological analysis of Gwithian demonstrate that the main components of Bronze Age fertilisers are domestic waste (e.g., bone, shell sand, animal dung, and ashes from wood, and grasses). Thin section description and interpretation of early Bronze Age phase I (layer 8 \& 7 = G7, G8 \& G10) shows presence of rubified fine mineral together with decomposed wood, burnt wood, ashes, animal dung, shells and bones suggesting that the arable soils were maintained by household waste dominated by fire residue. This interpretation is supported by silt sized grain, which are grey in PPL and XPL, interpreted as ash particles.

The results also show bioturbation (mixing by soil biota) has also taken place in these samples. The presence of planar voids and channel structures is interpreted as indication of ploughing. This fact is also supported by the presence of clays 
coatings darkened by organic material, which is interpreted for tillage activity. Occurrence of phytoliths suggests a significant herbivore dung component. The distribution pattern shows that the soils were very much disturbed by soil animals such as earth worms. Earthworm/slug granules are found, but the presence of channels and chambers and excremental micro aggregates in the other contexts show that bioturbation (mixing by soil biota) has also taken place in these samples.

Second phase of early Bronze (Layer 6 = sample G6) is represented by banded horizon which is comprised of clean windblown sand. Thin section analysis of second phase of early Bronze Age represents single grain micro structure which is occurred in coarse sandy soils and some strongly leached horizons. Single grain structure is inherited from the parent's material removal of fine particles of vertical leaching or later differential corrosion. The soils have simple packing voids which are resulted from the random packing of mineral grains and thus often show relict sedimentary feature of soil parent material. The course organic material is rarely found from this horizon. There are rare traces of bone, decomposed wood, and charred wood. The fine material has low birefringence. Rare clay coating on the grains are also identified. Presence of very rare discontinuous fine organic material coatings on grains are also noticed. The presence of very fine organic material around sand grains and occurrence of clay coating may indicate that organic material was used from manuring.

The III phases also belong to Early/Middle Bronze Age (layer 5, Sample G5), which are represented by banded horizon. It is comprised of clean windblown sand. Coarse organic material is absent from this horizon. No traces of bone, charred-wood is recorded from this phase. Field observation suggested that Bronze Age farmers neglected this area for farming [1]. However, soil aggregates surrounded by fine material may indicate that arable soils were raised by manuring practice. Moreover, few traces of porous material are also identified, which is interpreted as bone. These evidences demonstrate that humans were present during this phase.

Phase IV belongs to Middle Bronze Age and represented by blown sand. Context number 602 and no 605a (G3, G9) and context no 605a (G4) belong to this horizon. The thin section analysis of G4 shows that the midden materials (e.g., charred/uncharred wood, ashes from wood and grasses, bone, phytoliths, and animal dung) are noticed from sandy horizons of 602 (4), which indicates that the sand horizons were not only stabilised by midden material, but it was also used as a manure. Thin section analysis proves our hypothesis. Moreover, this hypothesis is also supported by occurrence of very few slightly weathered quartzes grains and the occurrence of iron depleted sandstone with stone rims. Iron depletion must have taken place before deposition as the acidification process required to form them would not have occurred in the calcareous depositional environment. Phytoliths are clear, suggesting an organic input.
Evidence of burning is evident from the occurrence of small oxidized stones, fine charcoals, big fragments of charred wood and rubified iron nodules. These are prominent features within the thin sections and give the impression that burning was in abundance. Ash particles were also identified, formed in settlement hearths because of burning manure with fine pale grey material evident in all the thin sections, together with very few linear patterns of oxidized stone. The ubiquitous occurrence of small bone fragments in the fossil soil horizons further testifies to the application of domestic waste material during these phases.

The soil sequences of Phase IV at Gwithian sand horizon (layer4=G4) are very similar to the sequences of buried soil and blown sands recorded on number of prehistoric sites in the northern and western Isles of Scotland. Earlier, it was thought that the sandy soils were created by sandy storms. However, Fowler [74] hypothesized that the sand horizon 602 (layer4=Phase IV) is a blown sand and that has been stabilized through the addition of midden material. Moreover, thin section analysis on sites in western Isles has demonstrated that many natural soils were made by human activities. These activities are created by dumping midden materials onto shifting sands. The cases-studies regarding prehistoric manuring practices from Northern Isles of Scotland and England demonstrate that midden heaps were not only ploughed insitu, but it was also intentionally disbursed over the sandy fields during Neolithic, Bronze and Iron Age. The examples of the Neolithic midden cultivations in UK are from Pool, Sanday, Orkney, Tofts Ness or Old Scatness, Shetland, Skara Brae, Noltland, Westray, and Hazleton North, Gloucestershire. It is suggested that the Neolithic farmers did not only cultivated earlier midden, probably created during the Mesolithic period, but they have also those from their own creations. The examples are from Northton, Harris, in the Outer Hebrides and a Mesolithic midden located near Prestatyn, on the north coast of Wales, also appears to have been cultivated in the Neolithic.

The Bronze Age and Iron Age farmers (from Old Scatness in Shetland and on several sites in the Western Isles) also stabilized sandy soil using midden material. The examples usage of domestic as manure are also from Cill Donain, South Uist, Baleshare, North Uist, Hornish Point, South Uist, few Iron Age sites in Shetland and Hallshill in Northumberland, England. The intensive cultivation of middens is reported from UK during Neolithic, Bronze and Iron age at Old Scatness, Shetland. The domestic waste and cultivation of middens in prehistory were not only used as manure, but it was also used to stabilise the sandy soils.

Middle/Late Bronze Age is corresponded to phase $\mathrm{V}$ which is equivalent to layer 3 (601=G2 \& G2). Field observations shows that ard marks were recorded overlying and below later midden and they are also noticed at the surface of the phase 4 horizons. Presence of dusty clays also prove the ploughing activity. 
The soils were fertilized through bone, and animal dungs and ashes. The evidence charred wood and rubified iron nodule may indicate that ashes were the main component of manuring practices. Presence of phytoliths also gives an indication of organic use as fertilizers.

Shell fragments are abundantly found in all five phases of Bronze age. They are occurred with bones; charred wood gives an indication that shell might be used as fertilizers. It is matter of debate, if shell fragments are naturally part of soil aggregates or the farmers has intentionally added them in arable soils to increase the soil fertility. The practice of addition of shell fragments in arable soil was not common until early first millennium AD in Ireland and the late 14th century in UK. If the interpretations about the intentional addition of shell fragments within arable soils is correct, it can be suggested that the Bronze Age Gwithian farmers might be the first who used shell fragments as fertilizers in Britain. Domestic waste was important constituents for manuring practices in Gwithian during the Bronze Age [75-79]. The intensified arable production evident in the Bronze Age may have been necessary to feed a growing population, or a surplus may have been grown for trade.

\section{Future Work}

Thin section analysis demonstrates that bones, ashes, phytoliths and pottery are rarely recorded from the Middle Bronze Age horizons (606) at Gwithian. The absence of organic material can be interpreted through the fact these archaeological materials might went through diagenetic process that alter the chemical signature of ash, bone, and phytoliths in variety of environment [80]. It will be interesting to study whether the bone concentrations are in primary milieu or in the secondary burial context by differential dissolutions. Fourier Infrared (FTIR) spectroscopy should be used to map the distribution patterns of archaeologically derived authigenic minerals in the archaeological sediments at different stratigraphical levels, to describe the areas in which ash mineral (calcite) is preserved, as well as zones in which apatitic bone mineral (dahllite) is conserved. Furthermore, this future study will help to identify the chemical "reaction rim" form on rocks buried in archaeological sediments by examining the various stages of dissolution and re-precipitations. The temporal and spatial distribution patterns of authigenic (insitu) minerals will be compared. In addition, the resulted diagenetic conditions will be compared with sites associated with prehistoric farming. These studies will be useful to investigate whether the humans were absent on site as they never visited it or as the minerals related to archaeology are precipitated because of dissolution processes.

Ashes are main constituents of prehistoric manuring practices. FTIR and Raman spectroscopy should also be applied to investigate the multifaceted chemical changes that ash undergoes in variety of environments related to prehistoric farming. Raman spectroscopy should be used for the identification of elements related to iron, manganese, and aluminium oxides, as well as organic residues, which provide important fingerprints for both high-temperature and diagenetic processes occurred within prehistoric hearths. Moreover, multi-element analysis by ICPMS should also be employed to identify the former fertilizations practices and the land use, which is more useful than traditional phosphate analysis.

\section{Acknowledgement}

This work is funded by HSP Huygens Fellowship and Vrije University Scholarship programme. Many Thanks go to Professor Dr. Henk Kars (former director of the institute) for choosing me for research training programme at the Institute of Geo and Bioarchaeology in Vrije University, Amsterdam. Netherlands. I am deeply thankful to Dr. Erika Guttman Bond for her guidance and teaching me micromorphology, and providing thin sections, without which this research paper would not have seen the light of the day. Moreover, I am beholden to her for her constant encouragement and scientific discussions, which help me broaden my knowledge in soil micromorphology. It is his most enlightening helps that drew my attention to this complex and yet a challenging area. I owe my sincere thanks to her constant inspiration that has made this research possible. I also want to thank Mrs. Shaskya Kars, technician electron microscope Laboratory, for providing laboratory facilities. Special thanks to Dr. A.R. Sankhyan for reviewing this manuscript.

\section{References}

1. Nowakowski JA, Sturgess J, Jons AN, Davies P, Gutmann EB, et al. (2007) Archaeology Beneath the Towans, Excavations at Gwithian, Cornwall, 19491969, Cornwall. Updated Project Design for Assessment, analysis and publication, An HES report to English Heritage Report No: $2007 R 017$.

2. Crombè P, Robinson E (2014) C-14 dsates as demographic proxies in Neolithisations models of northwestern Europe: a critical assessment using Belgium and northeast France as a case-study. Journal of Archaeological Science 52: 558-566.

3. Boserup E (1965) The conditions of agricultural growth: The economics of agrarian change under population pressure. Allen \& Unwin, London.

4. Guttmann EB (2001) Continuity and change in arable land management in the Northern Isles: evidence from anthropogenic soils, Unpublished doctoral dissertation, Department of Environmental Science, University of Stirling, Scotland, UK.

5. Guttmann EBA (2001b) Minehowe: the geoarchaeological analysis. unpublished report, Orkney Archaeological Trust.

6. Guttmann EB, Simpson IA, Davidson DA (2005) Manuring practices in antiquity: a review of the evidence. In: Brickley M, Smith D (Eds.), Fertile Ground: Papers in Honour of Susan Limbrey. Oxbow Books, p. 68-76.

7. Guttmann EB, Simpson IA, Davidson DA, Dockrill SJ (2006) The management of Arable Land from Prehistory to the Present: Case Studies from the Northern Isles of Scotland Geoarchaeology 21(1): 6192.

8. Guttmann EB, Jennifer AJD, Brown A, Bull ID, Evershed RP (2016) Early Neolithic agriculture in county Mayo, Republic of Ireland: Geoarchaeology of the Cìde fields, Belderring, and Rathlackan. Journal of the North Atlantic 30: 1-32. 


\section{Global Journal of Archaeology \& Anthropology}

9. Davidson DA, Carter SP (1998) Micromorphological evidence of past agricultural practices in cultivated soils: the impact of a traditional agricultural system on soils at Papa Stour, Shetland. Journal of Archaeological Science 25: 827-838.

10. Bakels CC (1997) The beginnings of manuring in Western Europe. Antiquity 71: 442-445.

11. Guttmann ER, Simpson IA, Dockril SJ (2003) Joined-Up Archaeology at Old Scatness, Shetland: Thin Section Analysis of the Site and Hinterland. Environmental Archaeology 8(1): 1-17.

12. Guttmann EB, Dockrill SJ, Simpson IA (2004) Arable agriculture in prehistory: new evidence from soils in the Northern Isles. Proceeding Society Antique Scotland, UK, 134: 53-64.

13. Guttmann EB, Simpson IA, Nielsen N, Dockrill SJ (2008) Anthropogenic soils in Iron Age Shetland: Implications for arable and economic activity. Geoarchaeology 23(6): 799-823.

14. Simpson IA, Guttmann EB, Shepherd A (2006) Characterising midden in Neolithic settlement construction: an assessment from Skara Brae, Orkney. Geoarchaeology 21(3): 221-235.

15. Bogaarda A, Frasera R, Heatonb THE, Wallacec M, Vaiglovaa P, et al. (2013) Crop manuring and intensive land management by Europe's first farmers. Proceedings of the National Academy of Sciences of the United States of America 110(31): 12589-12594.

16. Lauer F, Prost K, Gerlach R, Patzold S, Wolf M, et al. (2014) Organic Fertilization and Sufficient Nutrient Status in Prehistoric Agriculture? - Indications from Multi-Proxy Analyses of Archaeological Topsoil Relicts. PLOS ONE 9(9): 1-19.

17. Nielson NH, Kristiansen MS (2014) Identifying ancient manuring: Traditional phosphate vs. multi-element analysis of archaeological soil. Journal of Archaeological Science 42(1): 390-398.

18. Styring A, Rosch M, Stephans E, Stika HP, Fischer E, et al. (2017) Centralisation and long-term change in farming regimes: Comparing agricultural practices in Neolithic and Iron Age south-west German Proceedings of the Prehistoric Society 83: 357-381.

19. Iversen J (1941) Land occupation in Denmark's Stone Age. Danmarks Geologiske Undersogelse 11(66): 1-68.

20. Bogaard A (2004) Neolithic Farming in Central Europe. Routledge, London, UK

21. Rösch M, Biester H, Bogenrieder A, Eckmeier E, Ehrmann O, et al. (2017) Late Neolithic Agriculture in Temperate Europe- A Long-Term Experimental Approach 6(11): 2-17.

22. Thomas J (1991) Rethinking the Neolithic. Cambridge, USA.

23. Whittle A (1996) When did Neolithic farmers settle down?, British Archaeology, 16: 7

24. Bogaard A, Heaton THE, Poulton P, Merbach I (2007) The impact of manuring on nitrogen isotope ratios in cereals: Archaeological implications for reconstruction of diet and crop management practices. Journal of Archaeological Science 34(3): 335-343.

25. Dimbleby GW (1962) The development of British heathland and their soils. Oxford Forestry Memoir, UK.

26. Spek T (1992) The age of plaggen soils. Wageningen Studies in Historical Geography. DLO Winand Staring Centre, Wageningen, Netherlands.

27. Buurman J (1998) Economy and Environment in Bronze Age, West Friesland, Noord Holland (from wetland to wetland). In: P Murphy \& C French (Eds.) The exploitation of wetlands. Oxford British Archaeological Reports. British Series 186. Symposium of the association for Environmental Archaeology pp. 267-292.

28. Fokken H (1982) Late Occupations near Bornwind. Palaeohistoria 24 91-113.
29. Brück J (2001) Bronze Age landscapes: tradition and transformation Published Oxford: Oxbow Books, Oxford, UK

30. Macphail RI (1990) The Soils. In: Saville A (Eds.), Hazleton North, Gloucestershire, 197982: The Excavation of a Neolithic Long Cairn of the Cotswold-Severn Group. London: Historic Buildings and Monuments Commission for England. Archaeological Reports 13: 4771.

31. Romans JCC, Robertson L (1983) An account of the soils at North Mains. In: Barclay GJ (Eds.), Sites of the third millennium BC to the first millennium AD at North Mains, Strathallan, Perthshire. Proceedings of the Society of Antiquaries of Scotland, UK, 113: 122-181.

32. Blume HP, Hoffmann D, Reichstien J (1987) Ein bronzezeitlicher Auftragsboden in Rantum. In: Kossack (Eds.), p. 33-45.

33. Harck 0 (1987) Archaologisches zur Kenntnis des vor und fruhgeschichtlichen Ackerbaus p. 1-50.

34. Stevenson JB (1984) The excavation of a hut circle at CùlaBhaile, Jura. Proceedings of the Society of Antiquaries of Scotland 114: 127-160.

35. Buteux S (1997) Settlements at Skaill, Deerness, Orkney: Excavations by Peter Gelling of the Prehistoric, Pictish, Viking and Later Periods, British Archaeological Reports, Oxford, UK, pp. 260.

36. Hunter J (2007) Investigations in Sanday, Orkney. Volume 1 excavations at Pool, Sanday. A multi-period settlement from Neolithic to Late Norse times. Kirkwall: The Orcadian Ltd in association with Historic Scotland, UK

37. Clarke DV, Hope R, Wickham Jones C (1978) The Links of Northland. Current Archaeology 6(2): 44-46.

38. Mackie Dawson LA, Mullins CE, Goss MJ, Court MN, Fitz Patrick EA (1989) Seasonal changes in the structure of clay soils in relation to soil management and crop type: II. Effects of cultivation and cropping at Compton Beauchamp. Journal of Soil Science 40: 283-292.

39. Simpson DDA (1976) The later Neolithic and Beaker settlement site at Northton, Isle of Harris. In: Burgess, C. and Miket, R. (Eds.), Settlement and Economy in the Third and Second Millennia B.C. Oxford: British Archaeological Report 33: 221-232.

40. Gilbertson DD, Schwenninger JL, Kemp RA, Rhodes EJ (1999) Sanddrift and soil formation along an exposed North Atlantic coastline: 14,000 years of diverse geomorphological, climatic and human impacts. Journal of Archaeological Science 26: 439-269.

41. Barber J (2003) Bronze Age Farms and Iron Age Farm Mounds of the Outer Hebrides.

42. Vander Veen M (1992) Crop husbandry regimes Sheffield: Sheffield Archaeological Monographs p. 3.

43. Simpson IA, Dockrill SJ, Lancaster SJ (1998b) Making arable soils: anthropogenic soil formation in a multiperiod landscape, pp. 111126. In: Nicholson RA, Dockrill SJ (Eds.), Old Scatness Broch, Shetland: Retrospect and Prospect. University of Bradford/Shetland Amenity Trust/North Atlantic Biocultural Organisation, Bradford, UK.

44. Troels Smith J (1984) Stall feeding and field manuring in Switzerland about 600 o years ago. Tools and Tillage 5(1): 13-25.

45. Barker G (1985) Prehistoric Farming in Europe. Cambridge University Press, Cambridge, USA.

46. Nielsen BO, Mahler V, Rasmussen P (2000) An arthropod assemblage and the ecological conditions in a byre at the Neolithic settlement at Weier, Switzerland, Journal of Archaeological Science 27: 209-218.

47. Simpson IA, Dockrill SJ, Bull ID, Evershed RP (1998a) Early anthropogenic soil formation at Tofts Ness, Sanday, Orkney. J Archaeol Sci 25: 729-746

48. Fenton A (1978) The Northern Isles: Orkney and Shetland. Edinburgh, Scotland, UK. 


\section{Global Journal of Archaeology \& Anthropology}

49. Haggarty AM (1991) Machrie Moor, Arran; recent excavations at two stone circles. Proceedings Society for Antiquity Scotland, 121: 51-94.

50. Bieleman J (1992) Geschiedenis van delandbouw in Nederlands. Boom, Meppel, Netherlands.

51. Schrank G (1995) An Orkney State: Improvements at Graemeshall, 1827-1888. Tuckwell Press, East Linton, Scotland, UK.

52. Daniel D, Scot B, Scot MT (2008) The Coastal Geomorphology of North Cornwall: St. Ives Head to Trevose Head. Wave Hub Impact on Seabed and Shoreline Processes (WHISSP). University of Plymouth Press, UK.

53. Fowler PJ, Thomas AC (1962) Arable Fields of the Pre-Norman Period at Gwithian, Cornish Archaeology 1: 61- 84.

54. Thomas AC (1958) Gwithian: Ten Years' Work (1949-1958) West Cornwall Field Clu.

55. Fitz Patrick EA (1993) Soil microscopy and micromorphology. Wiley, Chichester, England, UK.

56. Courty MA, Goldberg P, Macphail R (1989) Soils and micromorphology in archaeology. Cambridge University Press, Cambridge, USA.

57. Bullock P, Federoff N, Jongerius A, Stoops G, Tursina T (1985) Handbook for soil thin section description. Waine Research Publications, Wolverhampton, England, UK.

58. Adderley WP, Wilson CA, Simpson IA, Davidson DA (2010) Anthropogenic Features. In: Stoops G, Marcelino V, Mees F (Eds.), Interpretation of Micromorphological Features of Soils and Regoliths. Elsevier, Amsterdam. pp. 569-588.

59. Francis GS, Cameron KC, Kemp RA (1988) A comparison of soil porosity and solute leaching after six years of direct drilling or conventiona cultivation. Australian Journal of Soil Research 26: 637-649.

60. Stoops G, Mathieu C, Maryam A, Gholamreza K (1988) Micro morphometric aspects of transformations of the macroporosity in irrigated soils. Egyptian Journal of Soil Science 28: 339-348.

61. Lamande M, Hallaire V, Curmi P, Peres G, Cluzeau D (2003) Changes of pore morphology, infiltration and earthworm community in a loamy soil under different agricultural managements. Catena 54: 637-649.

62. Jongerius A (1983) Micromorphology in agriculture. In Bullock, P. \& Murphy, C.P. (Eds.), Soil Micromorphology. Techniques and Applications. AB Academic Publishers, Berkhamstead 1: 111-138.

63. Brewer R (1976) Fabric and mineral analysis of soils. Robert E. Krieger Pub Co, Huntington, New York, USA.

64. Usai MR (2001) Textural features and pre-Hadrian's Wall ploughed Paleosols at Stanwix, Carlisle, Cumbria, UK, Journal of Archaeological Science 28: 541-553.

65. Usai MR (2005) Textural pedofeatures as tools to diagnose past cultivation - a controlled experiment. In: Smith DN, Brickley, MB, Smith W (Eds.), Fertile Ground. Papers in Honour of Susan Limbrey. Oxbow Books, Oxford, 162-164.
66. Dalrymple JB, Theocharopoulos SP (1987) Intrapedal cutans. Lateral differences in their properties and their spatial clustering. Geoderma 41: 149-180.

67. Kühn P, Aguilar J, Miedema R (2010) Textural features and related horizons. In: Stoops G, Marcelino V, Mees F (Eds.), Interpretation of Micromorphological Features of Soils and Regoliths. Elsevier, Amsterdam pp. 217-250.

68. Carter S (1998) The use of peat and other organic sediments as fuel in northern Scotland: Identifications derived from soil thin sections. In: Mills \& G. Coles (Eds.), Life on the edge: Human settlement and marginality. Oxford: Oxbow Books, pp. 99-103.

69. Simpson IA, Vésteinsson O, Adderley P, McGovern TH (2003) Fuel resource utilisation in landscapes of settlement. Journal of Archaeological Science 30: 1401-1420.

70. Gutmann EB (2007) Soil Assessment of Gwithian. In: Nowakowski et al. (Eds.), Archaeology Beneath the Towans, Excavations at Gwithian, Cornwall, 19491969. Cornwall. Updated Project Design for Assessment, analysis and publication, An HES report to English Heritage Report No: 2007R017.

71. Adderley WP, Simpson IA, Davidson DA (2006) Historic landscape management: A validation of quantitative soil thin-section analyses. Journal of Archaeological Science 33(3): 320-334.

72. Adderley WP, Alberts IL, Simpson IA, Wess TJ (2004) Calcium-ironphosphate features in archaeological sediments: Characterisation through microfocus synchrotron X-ray scattering analyses. Journal of Archaeological Science 31: 1215-1224.

73. Davidson DA, Dercon G, Simpson IA, Dalsgaard K, Spek T, et al. (2007) The identification and significance of inputs to anthrosols in northwest Europe. Atti della Societa ` Toscana di Scienze Naturali, Memorie Series A 112: 79-83.

74. Fowler PJ (1983) The farming of Prehistoric Britain. Cambridge University press, Cambridge, USA.

75. Jongerius A (1970) Some morphological aspects of regrouping phenomena in Dutch soils. Geoderma 4: 311-331.

76. Bellwood P (2004) First Farmers: The Origins of Agricultural Societies Blackwell Publisher, USA.

77. Blume HP, Kalk E (1986) Bronzezeitlicher Auftragsboden bei Rantum auf Sylt. Z. Pflanzenernähr. Bodenkd 85: 227-244.

78. Jones G (2005) Garden cultivation of staple crops and its implications for settlement location and continuity. World Archaeology, 37(2): 164176.

79. Kemp RA (1999) Micromorphology of loess-paleosol sequences: A record of paleoenvironmental change. Catena 35: 179-196.

80. Stoops G (2003) Guidelines for Analysis and Description of Soil and Regolith Thin Sections. Soil Science Society of America, Madison, Wisconsin, USA

This work is licensed under Creative

Commons Attribution 4.0 License

DOI: 10.19080/GJAA.2018.06.555687
Your next submission with Juniper Publishers will reach you the below assets

- Quality Editorial service

- Swift Peer Review

- Reprints availability

- E-prints Service

- Manuscript Podcast for convenient understanding

- Global attainment for your research

- Manuscript accessibility in different formats

( Pdf, E-pub, Full Text, Audio)

- Unceasing customer service

Track the below URL for one-step submission

https://juniperpublishers.com/online-submission.php 